\title{
Pengembangan LKPD Terintegrasi STEM-PjBL (Science, Technology, Engineering, and Mathematics- Project Based Learning) pada Materi Minyak Bumi
}

\section{Development of Integrated LKPD STEM-PjBL (Science, Technology, Engineering, and Mathematics- Project Based Learning) in Petroleum Material}

I Dwynda ${ }^{1^{*}}$ and Effendi ${ }^{1}$

1 Pendidikan Kimia, Universitas Negeri Padang, Jl. Prof. Dr. Hamka, Air Tawar Barat, Padang Utara, Sumatera Barat, Indonesia 25171

*dwyndain@gmail.com

ARTICLE INFO

Received 01 June 2020

Revised 16 June 2020

Published 03 July 2020

\begin{abstract}
Education 4.0 emphasizes $4 C$ skills, critical thinking, creativity, communication and collaboration. Realized with STEM-PjBL integrated learning, one of them was in the Petroleum material grade XI of SMA/MA. This study aims to produce STEM-PjBL integrated LKPD in Petroleum material and determine its validity. This type of research is $R \& D$ with a 4-D model composed of define, design, develop, and disseminate (not implemented). Research is limited to the validity test with the instrument validity as a measurement tool. Data collection techniques through questionnaires and analysis of research data from five expert validators using the Cohen kappa formula. Based on the analysis concluded, LKPD has had very high validity.
\end{abstract}

\section{KEYWORDS}

4-D Models, LKPD, Petroleum, R\&D, STEM-PjBL

\section{ABSTRAK}

Pendidikan 4.0 mengedepankan keterampilan 4C, critical thinking, creativity, communication and collaboration. Direalisasikan dengan pembelajaran terintegrasi STEM-PjBL salah satunya pada materi Minyak Bumi kelas XI SMA/MA. Penelitian ini bertujuan menghasilkan LKPD terintegrasi STEM-PjBL pada materi Minyak Bumi dan menentukan validitasnya. Jenis penelitian yaitu $R \& D$ dengan model 4 -D yang tersusun atas define, design, develop dan disseminate (tidak dilaksanakan). Penelitian dibatasi hingga uji validitas dengan instrumen validitas sebagai alat ukur. Teknik pengumpulan data melalui penyebaran angket dan analisis data hasil penelitian dari lima validator ahli dengan formula kappa Cohen. Berdasarkan analisis disimpulkan, LKPD yang dihasilkan memiliki validitas sangat tinggi.

\section{KATA KUNCI}

LKPD, Minyak Bumi, Model 4-D, R\&D, STEM-PjBL 


\section{PENDAHULUAN}

Indonesia di era pendidikan 4.0. berharap memiliki sumber daya manusia yang cerdas, sebagai sentral teknologi, pendidikan dan peradaban dunia ${ }^{[1]}$. Salah satu upaya peningkatan kualitas pendidikan dengan penerapan STEM dalam pembelajaran, karena STEM menggabungkan keterampilan 4-C abad 21 yaitu creativity (kreativitas), critical thinking (berpikir kritis), collaboration (berkolaborasi) dan communication (berkomunikasi) ${ }^{[2]}$. STEM mencakup empat disiplin ilmu yaitu sains (science), teknologi (technology), teknik (engineering) dan matematika (mathematics) $^{[3]}$.

STEM dapat menggunakan salah satu model pembelajaran yaitu Project Based Learning (PjBL), yang berlandaskan proyek/kegiatan sebagai media ${ }^{[4]}$. Project Based Learning memiliki enam tahapan pembelajaran, yaitu: 1) penyajian permasalahan; 2) merencanakan; 3) menyusun jadwal; 4) monitoring terhadap pengerjaan proyek; 5) penilaian; 6) evaluasi ${ }^{[5]}$. Pendekatan STEM dengan model PjBL dapat diaplikasikan pada materi kimia salah satunya yaitu Minyak Bumi. Materi Minyak Bumi dipelajari pada kelas XI semester 1 tingkat SMA/MA.

Berdasarkan angket didapati bahwa pembelajaran Minyak Bumi di SMAN 12 Padang menggunakan kurikulum 2013 revisi 2018, sedangkan untuk SMAN 1 Payakumbuh menggunakan kurikulum 2013 revisi 2016, dan untuk SMAN 4 Solok Selatan menggunakan kurikulum 2013. Dari hasil angket ketiga SMA tersebut, dinyatakan bahwa sebanyak $68 \%$ dari 60 peserta didik memiliki ketertarikan pada materi Minyak Bumi. Persentase ini menggambarkan bahwa Minyak Bumi menarik untuk dipelajari. Namun, sebanyak $57 \%$ peserta didik pada beberapa bagian materi Minyak Bumi merasa kurang paham, seperti dalam menjelaskan fraksi-fraksi minyak bumi dan teknik pemisahannya.

Upaya pendidik dalam menunjang pembelajaran yaitu menggunakan bahan ajar berupa Lembar Kerja Peserta Didik (LKPD), buku dan power point. Adanya alat bantu pembelajaran diharapkan mampu mendampingi buku teks untuk memantapkan konsep peserta didik. Salah satu alat bantu pembelajaran yang digunakan yaitu LKPD dari Intan Pariwara. Sebanyak 55\% peserta didik menganggap bahwa LKPD dapat membantu dalam memahami materi. Berbeda dengan pendapat guru, mengatakan LKPD yang tersedia belum memenuhi tuntutan kurikulum saat ini.

Berdasarkan orientasi di atas dikembangkanlah LKPD terintegrasi STEM-PjBL khususnya pada materi Minyak Bumi yang lebih sesuai dengan tuntutan, baik dari segi Tujuan Pendidikan Nasional Indonesia, guru dan peserta didik dengan 4-D sebagai model pengembangannya. LKPD terhasil memuat proyek sederhana berupa poster dan miniatur kilang minyak bumi sebagai kegiatan berbasis proyeknya. Melalui LKPD terintegrasi STEM-PjBL ini peserta didik diharapkan mampu berfikir secara 4C. Peserta didik lebih mandiri dan dapat berfikir secara kreatif dan aktif terutama dalam mencari informasi, berfikir secara kritis tentang permasalahan yang dijumpai, mampu berkomunikasi dengan teman dan guru terkait materi yang kurang/tidak dipahami serta berkolaborasi untuk menyelesaikan proyek yang telah ditentukan. Diharapkan LKPD tersebut dapat menjadi pendamping buku teks dalam melatih peserta didik untuk menyelesaikan tugasnya, dapat membantu pemantapan konsep bagi peserta didik. Untuk itu dilakukan penelitian dengan judul "Pengembangan LKPD Terintegrasi STEM-PjBL (Science, Technology, Engineering, Mathematics-Project Based Learning) pada Materi Minyak Bumi”.

\section{METODE}

Pada penelitian pengembangan LKPD ini, digunakan jenis penelitian yaitu Research and Development (R\&D) dengan 4-D sebagai model penelitiannya, digunakan untuk menguji apakah suatu produk yang dihasilkan telah efektiff[]. Penelitian ini dimaksudkan untuk menghasilkan LKPD terintegrasi STEM-PjBL khususnya pada materi Minyak Bumi untuk kelas XI MIPA SMA/MA. Model 4-D mempunyai empat tahapan: define, design, develop dan disseminate (tidak dilaksanakan) ${ }^{[7]}$. Subjek penelitian yaitu dua dosen Jurusan Kimia FMIPA UNP dan tiga guru mata pelajaran kimia SMA.

Prosedur yang dilakukan dalam pengembangan bahan ajar berupa LKPD ini diawali dengan tahap define, pada tahapan ini dilakukan analisis ujung depan yang bertujuan menentukan masalah yang mendasar pada pembelajaran, lalu analisis peserta didik guna mengetahui latar belakang peserta didik. Selanjutnya analisis tugas guna menentukan isi satuan pembelajaran, serta analisis identifikasi konsep yang akan diajarkan dan menyusunnya secara sistematis dan yang terakhir merumuskan tujuan pembelajaran.

Berikutnya design, tahap ini merupakan tahapan perancangan untuk menyiapkan perangkat pembelajaran. Diawali dengan menyusun tes acuan, pemilihan media yang cocok, pemilihan format yang mengacu pada negara-negara maju, rancangan awal untuk merancang bahan ajar sebelum diuji coba. Tahapan ini, LKPD dirancang berdasarkan judul, petunjuk belajar peserta didik, kompetensi yang wajib dicapai, tugas-tugas dan langkah kerja, serta penilaian ${ }^{[8]}$.

Ketiga develop, tahapan yang menghasilkan perangkat pembelajaran yang telah direvisi berdasarkan masukan para pakar. Tahapan ini, LKPD yang terhasil nantinya dilakukan tes validitas yang bertujuan untuk menguji valid atau tidaknya suatu produk. Dalam pengujian dilakukan uji validitas media berdasarkan content validity (validitas isi), melalui perbandingan isi instrumen dengan materi yang diajarkan dan construct validity (validitas konstruksi) yang dibantu dengan kisi-kisi sehingga dihasilkan lembar validasi. 
Produk LKPD yang telah dirancang akan divalidasi oleh lima validator, yaitu dua dosen Kimia FMIPA UNP dan tiga guru Kimia SMA/MA. Perlakuan ini bertujuan untuk melihat tingkat validitas uji coba LKPD terhasil. Kritik dan saran dari validator digunakan sebagai bahan merevisi LKPD. Selanjutnya, tahap revisi dilaksanakan perbaikan bagian-bagian yang kurang tepat dari LKPD. Revisi dihentikan jika validator menyatakan LKPD terhasil telah valid.

Proses validasi yang telah dilakukan didapati data primer yang diperoleh dari hasil LKPD terintegrasi STEM-PjBL pada materi Minyak Bumi oleh expert validator. Berikutnya penilaian, dengan penggunaan instrumen lembar validasi untuk mengetahui validitas konstruk dan validitas isi terhadap LKPD terhasil. Analisis validitas isi dan desain didasarkan pada categorical judgments yang dimodifikasi dari Boslaugh (2008). Pada categorical judgments, validator diberikan pernyataan. Lalu diberikan penilaian terhadap masingmasing pernyataan tersebut. Lembar yang diberikan berupa angket dan pada lembar terakhir diberikan kesempatan bagi validator untuk memutuskan hasil dari penilaian yang telah diberikan. Penilaian yang diberikan validator pada lembar validasi berupa skor disesuaikan dengan kriteria yang terdapat pada Tabel 1 . Tabel 1. Skor Lembar Validitas ${ }^{[9]}$.

\begin{tabular}{c|c|c|c|c} 
Jawaban & SS & S & TS & STS \\
\hline Skor & 4 & 3 & 2 & 1
\end{tabular}

Penilaian validator terhadap masing-masing pernyataan dianalisis dengan formula kappa Cohen, di mana di akhir didapati momen kappa.

$$
\text { momen kappa }(k)=\frac{\rho_{0}-\rho_{e}}{1-\rho_{e}}
$$

$$
\begin{aligned}
k= & \text { Momen kappa, menunjukkan validitas } \\
& \text { produk. } \\
\rho_{0}= & \text { Proporsi yang terlaksana, dihitung dengan } \\
& \text { cara skor ahli dibagi skor maksimal. } \\
\rho_{e}= & \text { Proporsi yang tidak terlaksana, skor } \\
& \text { maksimal dikurangi skor yang diberikan } \\
& \text { dibagi skor maksimal. }
\end{aligned}
$$

Tabel 2. Momen kappa $(k)^{[9]}$.

\begin{tabular}{c|c} 
Interval & Kategori \\
\hline $0,81-1,00$ & Very High \\
\hline $0,61-0,80$ & High \\
\hline $0,41-0,60$ & Intermediate \\
\hline $0,21-0,40$ & Low \\
\hline $0,01-0,20$ & Very Low \\
\hline$\leqslant 0,00$ & Invalid
\end{tabular}

Momen kappa penentu tingkat validitas produk yang terhasil dengan tingkat validitas disesuaikan dengan Tabel 2.

\section{HASIL DAN DISKUSI}

\subsection{Hasil Penelitian}

Berdasarkan penelitian yang telah dilaksanakan diperoleh LKPD terintegrasi STEM-PjBL pada materi Minyak Bumi dengan menggunakan jenis penelitian Research and Development dengan model 4-D, yang dibatasi hingga tahap develop/pengembangan dan tahapan disseminate (penyebaran) tidak dilaksanakan. Pada tahapan develop penelitian dilaksanakan sampai uji validitas yaitu menguji tingkat keabsahan produk terhasil. Gambaran umum LKPD terhasil dapat dilihat pada Gambar 1.
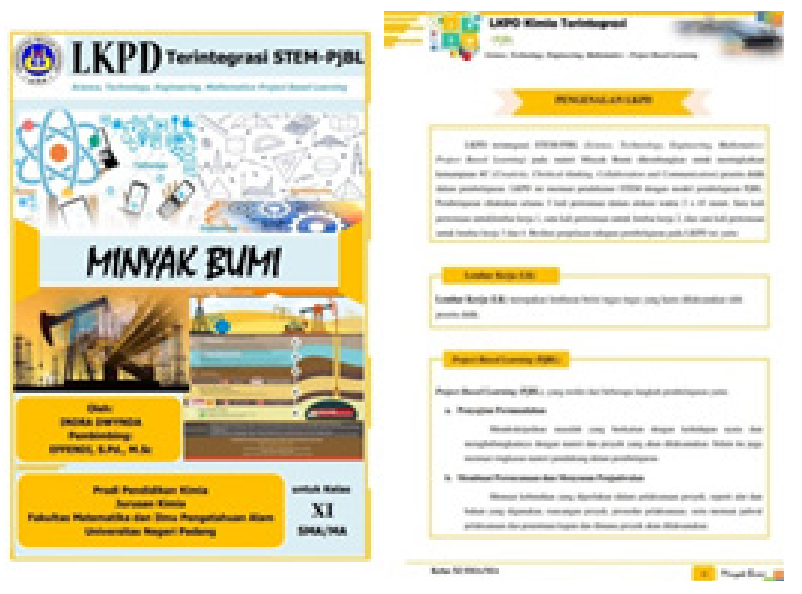

Gambar 1. Bentuk LKPD Terhasil.

\subsubsection{Tahap Define}

Tahapan ini dimulai dengan analisis ujung depan dilakukan melalui observasi 3 guru kimia dan angket yang diisi oleh 60 peserta didik dari SMAN 12 Padang dan SMAN 1 Payakumbuh dan SMAN 4 Solok Selatan yang dipilih berdasarkan kebijakan zoning school. Berdasarkan observasi yang telah dilaksanakan, diperoleh beberapa masalah diantaranya: 1) Masih terdapat materi Minyak Bumi yang belum dipahami oleh peserta didik; 2) LKPD yang digunakan belum tidak memiliki gambar destilasi fraksionasi untuk mendukung pemahaman, dan belum terintegrasi STEM-PjBL yang mampu meningkatkan kemampuan $4 \mathrm{C}$ yang didukung dengan pengerjaan proyek sederhana.

Pada analisis peserta didik diperoleh data berupa rentang usia peserta didik 15-17 tahun di mana $65 \%$ peserta didik menganggap materi Minyak Bumi menarik, namun 57\% peserta didik menganggap beberapa materi merasa kurang paham seperti menjelaskan fraksi-fraksi minyak bumi dan teknik pemisahan fraksi-fraksi minyak bumi serta $55 \%$ peserta didik menganggap penggunaan LKPD dalam pembelajaran dapat membantu pembelajaran. Pada analisis tugas dikerjakan analisis KD, kemudian diturunkan jadi IPK (Indeks Pencapaian Kompetensi), serta tujuan pembelajaran.

Pada analisis konsep dilaksanakan melalui identifikasi main concept serta penyusunan penyajian dan rincian konsep-konsep yang berkesesuaian secara 
Edukimia • 2020 • Vol. 2, No. 3

teratur. Dari tahapan ini diperoleh: (1) Analisis materi, berlandaskan dimensi pengetahuan berupa fakta, konsep, prinsip dan prosedur; (2) Analisis konsep, tersusun atas concept label, concept definition, concept attributes, concept hierarchy, concept type, examples and non examples hingga terbentuk suatu peta konsep.

Tujuan pembelajaran materi Minyak Bumi dengan pendekatan STEM dan model pembelajaran PjBL yang terintegrasi menjadi STEM-PjBL dengan menelusuri dari berbagai literatur, simple investigation and manage information, diharapkan

\section{Kelayakan Isi}
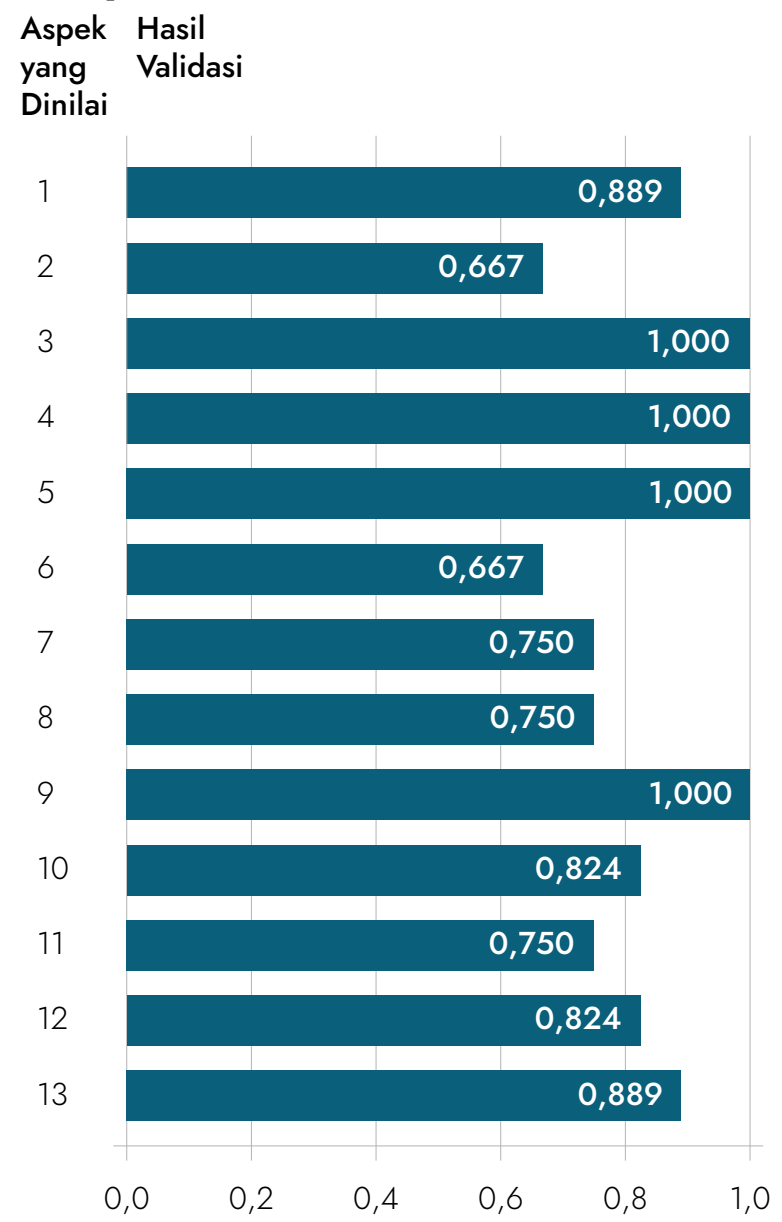

\section{Komponen Kebahasaan}
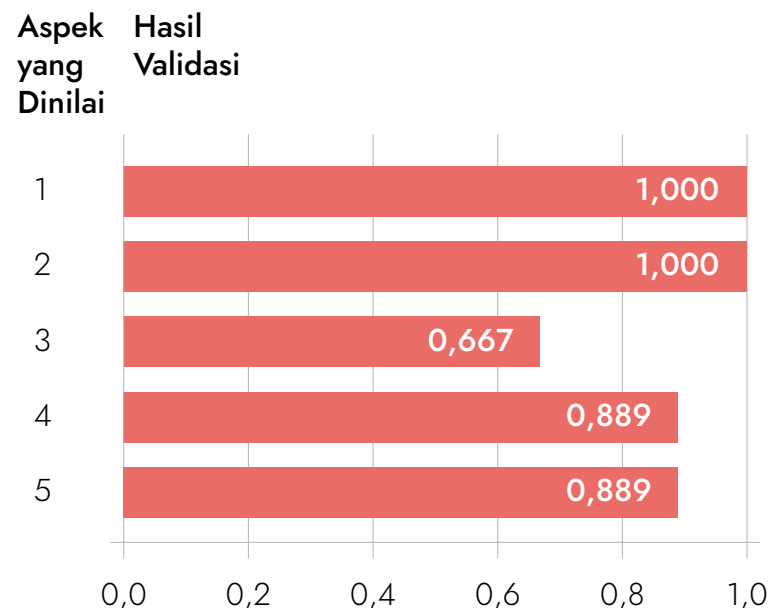

Gambar 2. Beragam grafik terkait poin 3.1.3. Tahap Develop, yakni Kelayakan Isi (kiri - atas), Komponen Penyajian (kanan - atas), Komponen Kebahasaan (kiri - bawah) serta Komponen Kegrafikan (kanan - bawah). aktifnya peserta didik, memiliki sikap want to know dan to be responsible dalam penyampaian argumen, answer the question, dan memberikan saran dan kritikan sehingga IPK yang diinginkan tercapai.

Berdasarkan analisis, disusun bahan ajar berupa LKPD terintegrasi STEM-PjBL pada materi Minyak Bumi. LKPD ini diharapkan mampu meningkatkan kemampuan 4C bagi peserta didik dan menghasilkan simple project dalam pembelajaran.

\section{Komponen Penyajian

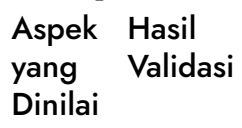

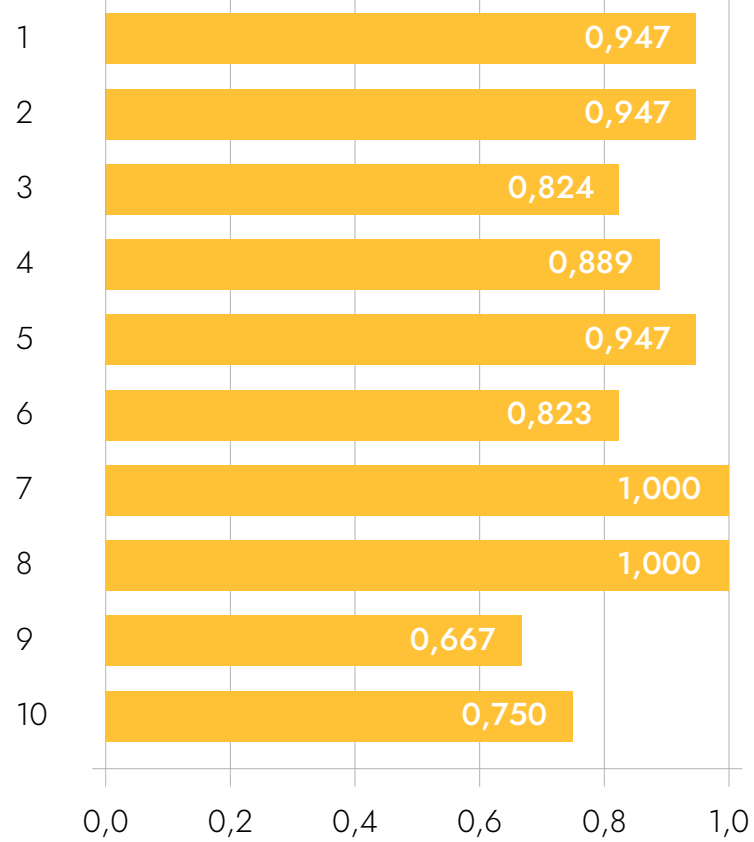

\section{Komponen Kegrafikan}

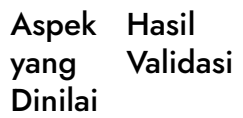

1

2

3

4

5

6

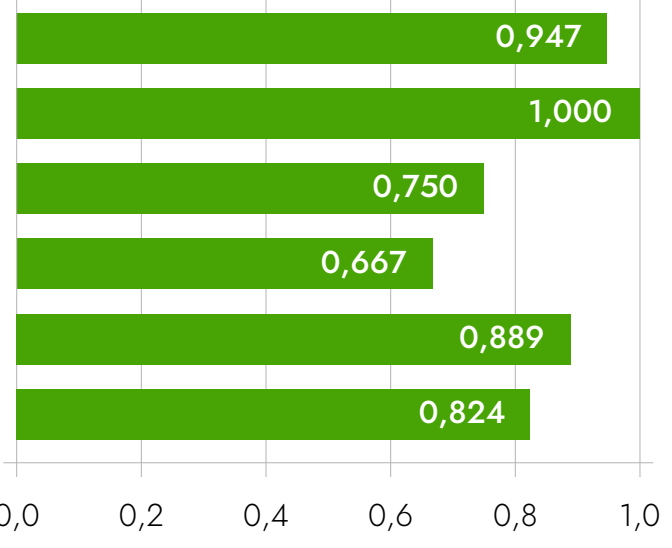

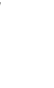




\subsubsection{Tahap Design}

Menghasilkan rancangan awal didasarkan tahap define. Format penulisan rancangan awal LKPD terintegrasi STEM-PjBL yaitu cover, halaman pendukung (kata pengantar, daftar isi, pengenalan LKPD, petunjuk penggunaan LKPD, identitas peserta didik), kompetensi yang akan dicapai (KI, KD, IPK dan Tujuan Pembelajaran), tugastugas dan langkah-langkah kerja, dan penilaian. Pembuatan LKPD diproses menggunakan Microsoft Word 2010.

\subsubsection{Tahap Develop}

Tahapan penilaian terhadap LKPD yang telah di-design didasarkan uji validitas ahli. Setiap tes dilaksanakan tahapan revisi berdasarkan saran dari setiap uji yang dilaksanakan. Pada tahap uji validitas LKPD yang telah dirancang dan dikembangkan, divalidasi oleh 5 orang validator yang terdiri dari 2 orang dosen Jurusan Kimia FMIPA UNP dan 3 orang guru bidang studi kimia. Uji validitas dilaksanakan dengan menilai didasarkan pada empat komponen yang terdiri atas kelayakan isi, komponen kebahasaan, komponen penyajian, dan komponen kegrafikan.

\subsubsection{Kelayakan Isi}

Berdasarkan Gambar 2 terlihat bahwa poin 2, menyajikan karya tentang proses pembentukan dan teknik pemisahan fraksi-fraksi minyak bumi beserta kegunaannya dan poin 6 yaitu membedakan kualitas bensin berdasarkan bilangan oktana-nya memiliki validitas kelayakan isi yang paling rendah yaitu 0,667 . Sedangkan yang paling tinggi pada poin $3,4,5$ dan 9 dengan nilai validitas 1 . Secara keseluruhan LKPD terintegrasi STEM-PjBL materi Minyak Bumi, setelah diukur dengan momen kappa memiliki validitas sangat tinggi untuk diujicobakan dengan nilai validitas sebesar 0,847.

\subsubsection{Komponen Kebahasaan}

Pada komponen kebahasaan, terlihat dari Gambar 2 bahwa poin 3 yaitu penggunaan kaidah bahasa yang baik dan benar memiliki validitas yang paling rendah sebesar 0,667. Sedangkan poin 1 keterbacaan huruf dan poin 2 kejelasan petunjuk dan informasi memiliki tingkat validitas yang tinggi sebesar 1 . Secara keseluruhan validitas untuk komponen kebahasaan memiliki nilai validitas 0,889 dengan kategori sangat tinggi untuk diujicobakan.

\subsubsection{Komponen Penyajian}

Grafik komponen penyajian pada Gambar 2 menjelaskan bahwa poin 9 (konsepkonsep pada materi Minyak Bumi) memiliki validitas paling rendah sebesar 0,667. Sedangkan yang validitas tertinggi pada poin 7 dan poin 8 yang memuat laporan proyek dan evaluasi memiliki validitas sebesar 1. Secara keseluruhan komponen penyajian memiliki tingkat validitas sangat tinggi untuk diujicobakan dengan nilai 0,879 .

\subsubsection{Komponen Kegrafikan}

Hasil analisis data penilaian komponen kegrafikan LKPD oleh validator seperti pada Gambar 2, validitas terendah pada poin 4 yaitu keteraturan tata letak dengan nilai validitas 0,667 sedangkan yang tertinggi memiliki nilai validitas yang paling tinggi pada poin 2 yaitu ketepatan penggunaan huruf. Secara keseluruhan diperoleh kappa 0,846 dengan kategori sangat tinggi untuk diujicobakan.

Rata-rata kappa validitas LKPD terintegrasi STEM-PjBL pada materi Minyak Bumi terhadap semua aspek yang dinilai oleh validator terlihat di Gambar 3.

\section{Hasil Uji Validitas LKPD terintegrasi STEM-PjBL pada Materi Minyak Bumi}

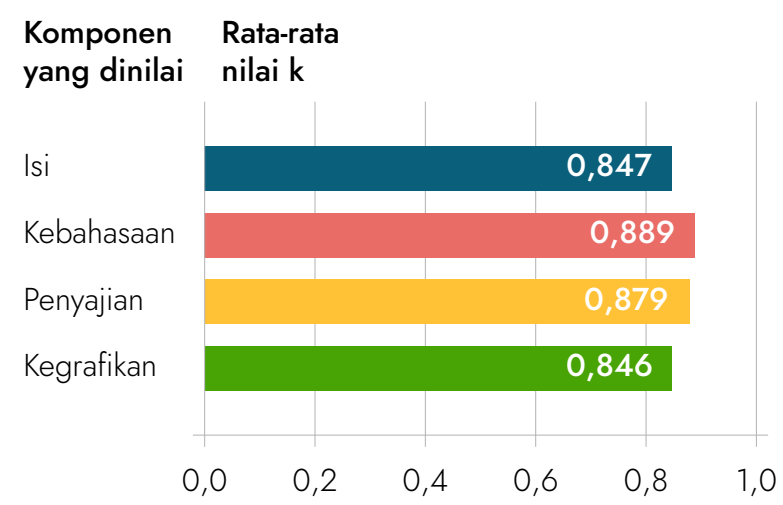

Gambar 3. Analisis Validasi LKPD materi Minyak Bumi.

Berdasarkan grafik, diperoleh hasil analisis validitas dari keempat komponen berturut-turut yaitu 0,$847 ; 0,889 ; 0,879$; dan 0,846 sehingga diperoleh rata-rata validitas LKPD berdasarkan momen kappa sebesar 0,865. Hasil tersebut menunjukkan bahwa LKPD yang dihasilkan telah valid dengan kategori kevalidan sangat tinggi untuk diujicobakan. Hasil validasi yang diperoleh dari validator selanjutnya direvisi untuk perbaikan LKPD yang lebih baik berdasarkan saran dari penguji dan validator.

\subsection{Pembahasan}

Penelitian ini mengharapkan hasil pengembangan yang berkualitas berdasarkan penilaian para pakar di bidangnya. Penentuan kualitas hasil pengembangan LKPD yang telah terhasil dilakukan berdasarkan kriteria valid atau tidaknya produk yang dikembangkan. Pengujian validitas dilakukan dengan penggunaan instrumen evaluasi untuk mengecek kesesuaian bahan ajar terhasil dengan kriteria ataukah perlu adanya perbaikan.

\subsubsection{Komponen Kelayakan Isi}

Berdasarkan grafik diperoleh kappa sebesar 0,847 dengan tingkat validitas sangat tinggi untuk diujicobakan. Penilaian ini merupakan penilaian terhadap kesesuaian isi LKPD yang terhasil 
dengan materi Minyak Bumi. Nilai momen kappa menyatakan LKPD yang dihasilkan telah sesuai dengan tuntutan kurikulum 2013 revisi 2018. Bahan ajar dikatakan valid jika memiliki kesesuaian dengan kurikulum yang ada. Kesesuaian isi dari segi kelayakannya dilihat berdasarkan model, pertanyaan dan latihan yang memiliki kesesuaian dengan model yang digunakan yaitu model PjBL (Project Based Learning). Isi dari LKPD juga memiliki kesesuaian dengan tujuan pembelajaran yang diharapkan tercapai.

\subsubsection{Komponen Kebahasaan}

Penilaian komponen kebahasaan pada LKPD yang dikembangkan memiliki nilai kappa 0,889 dan validitas untuk diujicobakan sangat tinggi. Aspek penilaian komponen kebahasaan meliputi: keterbacaan bentuk dan ukuran huruf, jelasnya informasi, kesesuaian dengan kaidah bahasa Indonesia yang baik dan benar serta kejelasan kalimat serta tidak menimbulkan kerancuan sehingga petunjuk maupun informasi di LKPD dipahami.

\subsubsection{Komponen Penyajian}

Penilaian komponen penyajian memperoleh rata-rata momen kappa sebesar 0,879 dengan validitas sangat tinggi untuk diujicobakan. Hal ini menunjukkan bahwa LKPD terhasil telah sesuai dengan IPK dan urutan penyajian materi berdasarkan model Project Based Learning (PjBL) yang tersusun atas: (1) penyajian permasalahan; (2) perencanaan dan penjadwalan proyek; (3) pembuatan proyek; (4) penilaian; dan (5) evaluasi.

\section{SIMPULAN}

Berdasarkan penelitian yang telah dilaksanakan diperoleh dua kesimpulan bahwa LKPD terintegrasi STEM-PjBL pada materi Minyak Bumi dapat dihasilkan menggunakan model pengembangan 4-D dan LKPD terhasil memiliki kriteria validitas sangat tinggi untuk diujicobakan dengan nilai momen kappa sebesar 0,865.

\section{REFERENSI}

1. Kementerian Pendidikan dan Kebudayaan Republik Indonesia. Peta Jalan Generasi Emas Indonesia 2045. Jakarta: Sekretariat Negara; 2017. 10-11 p.

2. Beers S. 21st Century Skills: Preparing Students for Their Future. 2011.

3. Force ST. Innovate: A blueprint for science, technology, engineering, and mathematics in California public education. Dublin, CA: Californians Dedictaed to Education Foundation; $2014.7 \mathrm{p}$.

4. Rusman. Belajar dan Pembelajaran Berorientasi Standar Proses Pendidikan. Jakarta: Kencana Media Grup; 2012. 396 p.

5. Sani RA. Pembelajaran Saintifik untuk Implementasi Kurikulum. Jakarta: PT. Bumi Aksara; 2018. $181 \mathrm{p}$.
6. Sugiyono. Metode Penelitian Kualitatif dan $\mathrm{R}$ \& D. Bandung: Alfabeta; 2012.407 p.

7. Thiagarajan, S; Semmel, D. S \& Semmel M. Instructional Development for Training Teachers of Exceptional Children: A Sourcebook. Indiana: Indiana University; 1974. 5 p.

8. Trianto. Mendesain Model Pembelajaran Inovatif-Progresif Konsep, Landasan, dan Implementasinya pada Kurikulum Tingkat Satuan Pendidikan (KTSP). Jakarta: Kencana Prenada Media Group; 2009. 189-192 p.

9. Boslaugh S, W. PA. Statistics in a Nutshell, a desktop quick reference. Beijing, Cambridge, Famham, Famham, Köln, Sebastopol, Taipei,Tokyo: O’reilly; 2008. 123-124 p. 